\title{
New sedimentological and structural data from the Ecemiş Fault Zone, southern Turkey: implications for its timing and offset and the Cenozoic tectonic escape of Anatolia
}

\author{
N. JAFFEY ${ }^{1} \&$ A. H. F. ROBERTSON ${ }^{1}$ \\ ${ }^{1}$ Department of Geology \& Geophysics, Grant Institute, West Mains Road, Edinburgh, EH9 3JW, UK \\ (e-mail:nj@glg.ed.ac.uk)
}

\begin{abstract}
The left-lateral Ecemiş Fault Zone, with a newly estimated displacement c. $60 \mathrm{~km}$, records important strike-slip deformation within Anatolia, prior to and during the Plio-Quaternary tectonic escape of the Anatolian 'microplate' along the well recognized right-lateral North Anatolian and the left-lateral East Anatolian Fault Zones. Mesozoic shallow-water carbonate deposition on the northern passive margin of a Tauride microcontinent was followed by southward ophiolite emplacement in latest Cretaceous time. Late Eocene final closure of one, or several, ocean basins within Central Anatolia further north caused further deformation, including large-scale north-vergent thrusting. Regional orogenic exhumation in the Oligocene to Mid-Miocene was accompanied by deposition of non-marine red-beds adjacent to the future Ecemiş Fault Zone and adjacent basins. Through-going left-lateral strike slip was initiated by the Mid-Miocene (or slightly earlier) and became become more transtensional/extensional during Pliocene-Quaternary time. Minor continuing left-lateral strike-slip is documented by stream offsets on major Plio-Quaternary alluvial fans shed from master fault scarps. The Ecemiş Fault Zone is, thus, identified as a regionally important strike-slip fault zone that was initially (Mid-Late Miocene) dominated by strike-slip and later (Pliocene-Quaternary) by extension.
\end{abstract}

Keywords: Turkey, Cenozoic, strike-slip fault, extrusion, tectonics.

As witnessed by large magnitude earthquakes during August 1999 (Izmit) and June 1998 (Ceyhan), Turkey is very seismically active, and includes important zones of active strike-slip faulting (Fig. 1a). Central Turkey has been interpreted as a zone of westward crustal extrusion, or 'tectonic escape' (Șengör et al. 1985), which has been accommodated by 80 $100 \mathrm{~km}$ of Late Miocene/Early Pliocene-Recent dextral offset along the North Anatolian Fault Zone (Westaway 1994) and 18-22 km of Pliocene (4-5 Ma)-Recent offset of the sinistral East Anatolian Fault Zone (Dewey et al. 1986; Fig. 1a). However, considerable crustal movement may have been taken along faults other than these two strike-slip systems by internal faulting and deformation within Anatolia, as discussed here.

This paper focuses on the Ecemiş Fault Zone (named by Yetiş 1984), a candidate for one such 'internal' strike-slip fault system. Others are the Tuzgölü Fault Zone with a poorly constrained offset (Çemen et al. 1999), and the sinistral Malatya-Ovacik Fault Zone with an estimated $29 \mathrm{~km}$ of sinistral offset during Early-Mid-Pliocene time (3-5 Ma) (Westaway \& Arger in press; Fig. 1a). The Ecemiş Fault Zone is the central section of the 'Central Anatolian Fault Zone' (Koçyiğit \& Beyhan 1998), a regionally significant sinistral strike-slip fault array extending across Turkey from Duzyayla (on the North Anatolian Fault Zone) in the north to Anamur in the south, a distance of c. $730 \mathrm{~km}$ (Koçyiğit \& Beyhan 1998; Fig. 1a). The Ecemiş Fault Zone exhibits a variable NNE-SSW to NE-SW orientation and divides the Taurus Mountains into two distinct parts (Eastern and Western Taurides). It remains uncertain whether the southern continuation of the Ecemiş Fault Zone runs (i) SW along the Namrun fault set (Fig. 1b, Koçyiğit \& Beyhan 1998) or (ii) SSW across the westernmost Adana Basin (Fig. 1b, Ünlügenç 1993); however, this study is mainly concerned with the Ecemiş Fault Zone further north.

The Ecemiş Fault Zone has been the subject of several studies over the past 20 years (Table 1; Yetiş 1978, 1984; Toprak \& Göncüoğlu 1993; Whitney \& Dilek 1997; Koçyiğit \& Beyhan 1998; Westaway 1999). Controversy currently revolves around the relative importance of this lineament prior to, or during, the time of known Plio-Quaternary westward extrusion of Anatolia. Recent publications have focused on whether the geomorphology of the Ecemiş Fault Zone represents the product of active strike-slip (Koçyiğit \& Beyhan 1998, 1999), or glacial scouring of an ancient fault zone which is no longer active (Westaway 1999). Here, we provide new structural, sedimentary and geomorphological evidence from the Ecemiş Fault Zone which, when combined with published stratigraphic and palaeomagnetic work, will be used to develop of new tectonic model in the regional context.

\section{Regional setting, stratigraphy and sedimentology}

In our study of the Ecemiş Fault Zone, we have focused on excellent exposures from Sulucaova in the north to Gülek in the south (Fig. 1b), where the majority of strike-slip indicators are found (Figs $2 \& 3$ ). In this region the Ecemiş Fault Zone dissects the Palaeozoic-Mesozoic Taurus Mountain chain, resulting in a topographic depression (50-1200 $\mathrm{m}$ of relief). This structure changes from a structural graben in the south to half-graben in the north (Fig. 1b).

The oldest sedimentary rocks are the Palaeocene Çamardi Formation and the Ulukişla volcanics, both marine and dated using benthic foraminifera (Figs 2 \& 3; Yetiş 1978). 

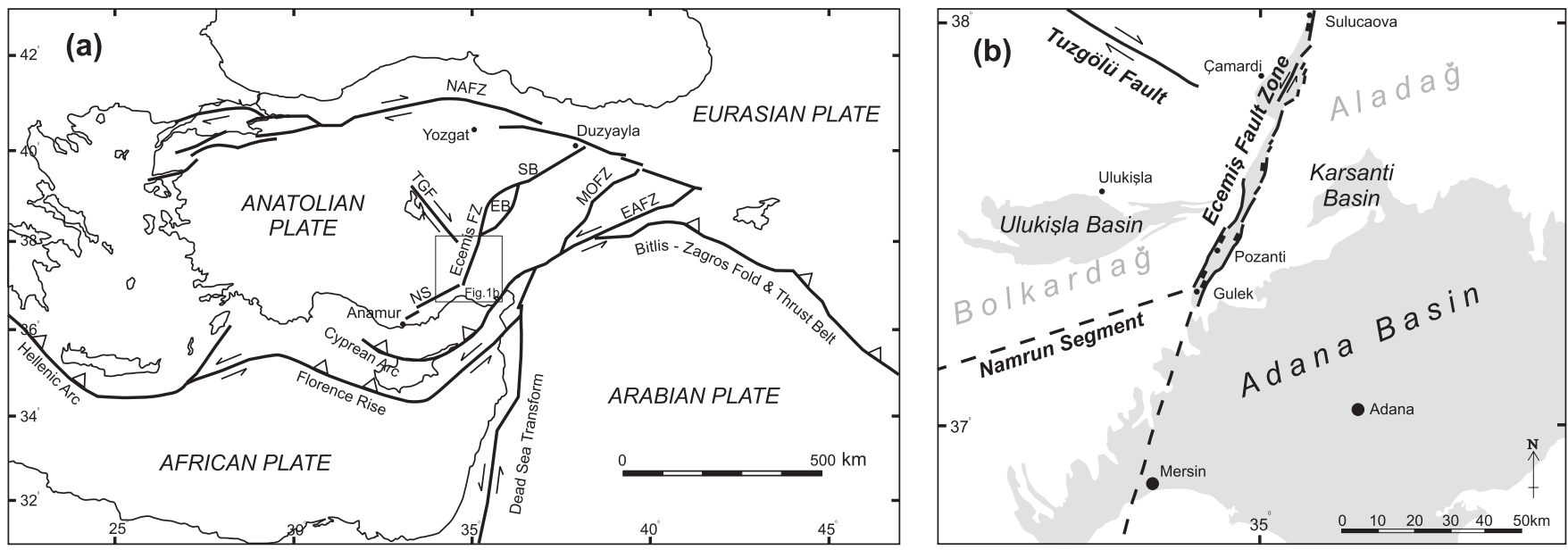

Fig. 1. Regional geological setting of the Ecemiş Fault Zone. (a) Simplified tectonic map of the Eastern Mediterranean region (modified after Șengör et al. 1985 and Koçyiğit \& Beyhan 1998). Solid lines are strike-slip faults; lines with triangles are thrust faults or subduction zones with triangles on the overriding block. Abbreviations: EAFZ, East Anatolian Fault Zone; EB, Erçiyes Basin; MOFZ, Malatya-Ovacik Fault Zone; NAFZ, North Anatolian Fault Zone; NS, Namrun Segment; SB, Sivas Basin; TGF, Tuzgölü Fault. (b) Enlargement of the Adana-Niğde region showing the location of Cenozoic sedimentary basins and tectonic lineaments.

Table 1. Summary of published results on timing and offset of the Ecemis Fault Zone

\begin{tabular}{lll}
\hline Reference(s) & \multicolumn{1}{c}{ Timing of movement } & \multicolumn{1}{c}{ Offset } \\
\hline Yetiș $(1978,1984)$ & $\begin{array}{l}\text { Main activity between Palaeocene and Mid-Eocene. Second } \\
\text { phase during Quaternary }\end{array}$ & - \\
Toprak \& Göncüoğlu (1993) & $\begin{array}{l}\text { Strike-slip activity in pre-Miocene time. Mainly normal } \\
\text { activity in post-Miocene times }\end{array}$ & - \\
Whitney \& Dilek (1997) & Main faulting occurred during Late Oligocene to Early & \\
Koçyiğit \& Beyhan (1998) & Miocene, synchronous with core complex exhumation & $75 \mathrm{~km}$ total sinistral offset \\
& Three phases of activity: & $24 \mathrm{~km}$ \\
Since Late Cretaceous & $3.1 \mathrm{~km}$ \\
$62 \mathrm{~km}$ total sinistral offset
\end{tabular}

Open-marine to shelf limestones (c. $130 \mathrm{~m}$ thick) unconformably overlie these rocks, dated at Lutetian (Middle Eocene) using benthic foraminifera, including Nummulites (Yetiş 1984). These sediments are unconformably overlain by a thick red bed-type succession (up to $1400 \mathrm{~m}$ apparent thickness) composed of terrestrial clastic sedimentary rocks including fluvial sandstones, mudstones, caliche, terrestrial debris flows (mainly pebblestones) and localized evaporitic lake facies. This succession is unfossiliferous; however, a Late Oligocene-Early Miocene age is inferred based on lithostratigraphic correlation with similar facies exposed in (i) the Karsanti Basin, $20 \mathrm{~km}$ east of the Ecemiş Fault Zone (apparent thickness 400 m, Fig. 1b) which contains well dated planktonic foraminifera and ostracods (Ünlügenç et al. 1993) of Oligocene age and (ii) the Atoprak Formation of the Ulukişla Basin (apparent thickness 900 m, Fig. 1), which is dated as Early Miocene, using freshwater ostracods (Nazik \& Gökçen 1992). In the south of the Ecemiş Fault Zone the Oligo-Miocene red-bed succession is unconformably overlain by shallow-marine oyster and echinoid-bearing limestones of Early Miocene (Burdigalian) age (Yalçin \& Görür 1984) which are seen to transgress from the south as far as Gülek (Fig. 3). However, these sediments are faulted in the vicinity of the Ecemiş Fault Zone and do not represent a simple post-tectonic transgressive cover. In the remainder of the Ecemiş Fault Zone area, the deformed red-bed sequence is unconformably overlain by a relatively flat lying unit of lacustrine algal limestones, fluvial sands and coals (c. $100 \mathrm{~m}$ thick) of Late Miocene age (based on ostracode dating, Yetiş 1978). The youngest sediments within the Ecemiş Fault Zone unconformably overlie this Late Miocene unit and are dominated by alluvial fans (50-1000 m thick) of inferred Pliocene-Quaternary age (Figs 2 and 3).

The approach employed here is to investigate the timing, offset and kinematic history of the Ecemiş Fault Zone by developing an understanding of the stratigraphic and tectonic development of the adjacent mountains and sedimentary basins, using the lines of evidence set out below.

\section{Palaeocurrents}

Palaeocurrents from the Oligo-Miocene red-bed succession of the Ecemiş Fault Zone (Fig. 4b) demonstrate fluvial drainage toward the north in the southern part of the area, flow toward the south in the northern sector, and east-west flow in the centre of the area. This indicates the existence of an inwarddraining basin, with a depocentre near the centre of the present Ecemiş Fault Zone. Palaeocurrent trends indicate the presence of source areas (palaeo-highs) surrounding the basin. Palaeocurrents from the Oligo-Miocene of the Ulukișla Basin further 


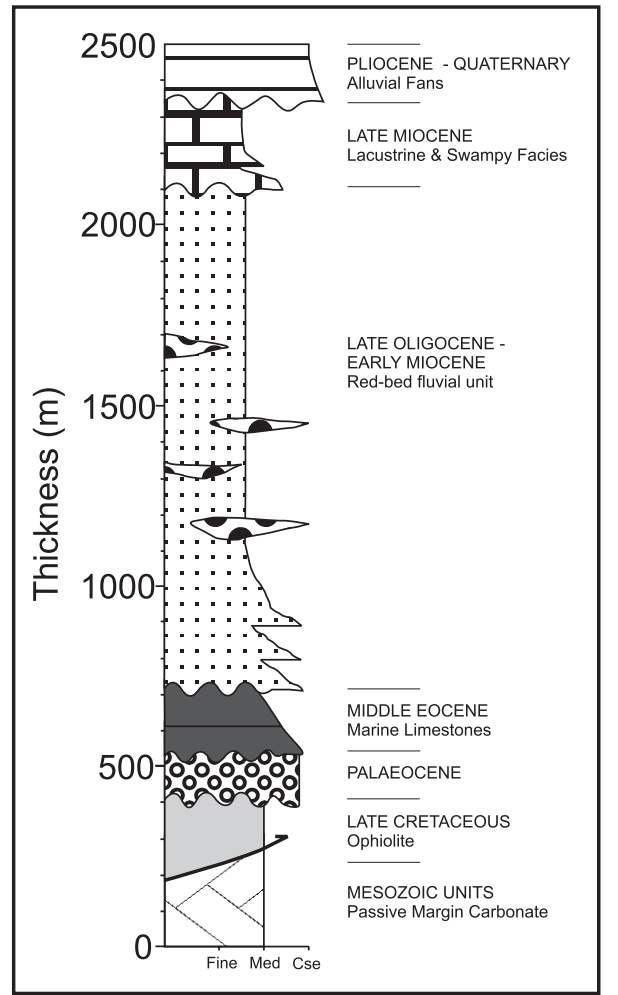

Fig. 2. Summary stratigraphic succession for the Ecemiş Fault Zone (central and northern parts).

west indicate flow from west to east, towards the Ecemiş Fault Zone (Fig. 4a).

At numerous sites along the fault zone (e.g. Akça in the Pozanti area, Fig. 4b) fine-grained fluvial mudstones are abruptly faulted against uplifted Mesozoic carbonates along the western bounding fault scarp of the Ecemiş Fault Zone. At these locations palaeocurrents within the lower fine-grained fluvial sedimentary rocks indicate flow directly away from the modern fault scarps (SE-directed), whereas higher in the succession flow becomes more axial to the basin (NE-directed). Also, fluvial channels are truncated near the faults. The above evidence (Fig. 4a) indicates that the Oligo-Miocene basin originally extended further to the east and west than at present, a view shared by Karedinizli \& Kazanci (1993). By contrast, pebble imbrication from the Plio-Quaternary fan complexes at Çamardi (Fig. 4d) demonstrate consistent transport away from modern fault scarps. Grain-size variations indicate that these sediments become finer-grained away from the modern fault scarps: Plio-Quaternary fans were thus shed directly from present-day fault scarps.

Palaeocurrent data, thus, demonstrate that a clastic basin existed in the area of the present Ecemiş Fault Zone during Oligocene-Miocene time, but cannot, alone, establish whether or not this was related to contemporaneous strike-slip or some other tectonic control. Similar Oligocene-Miocene clastic sediments in basins to the east (Karsanti Basin) and west (Aktoprak Fm of the Ulukişla Basin) of the Ecemiș Fault Zone (Fig. 1b) appear to relate to regional uplift of the Taurus Mountains (Dilek \& Whitney in press). Maximum exhumation, including lower crustal granitic rocks, took place in the Niğde Massif (Whitney \& Dilek 1997) along the eastern margin of the Ecemiş Fault Zone (Fig. 3). It is, thus, likely that

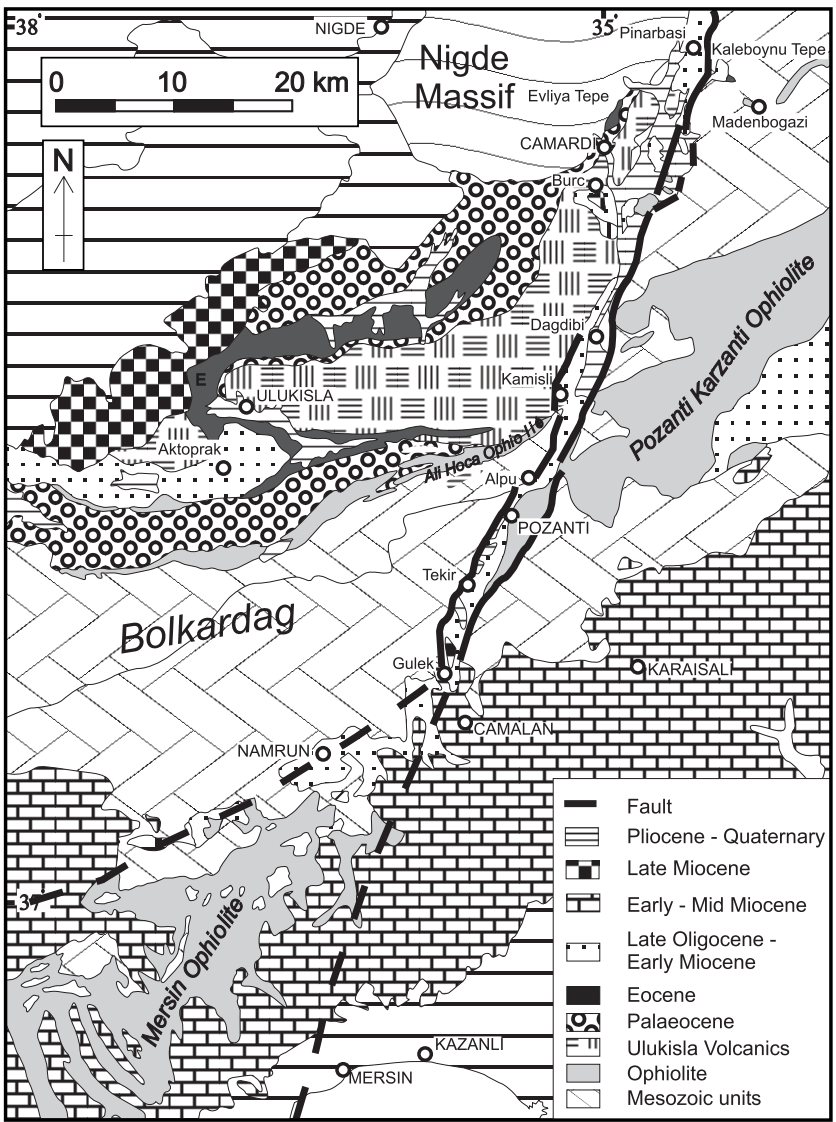

Fig. 3. Geological map of the Adana region after Özüpek \& Çevik (1962).

differential exhumation played a role in localizing a sedimentary depocentre in the vicinity of the Ecemiş Fault Zone during Oligo-Miocene time.

\section{Subsidence curves}

Composite logs from each of the Ecemiș, Ulukişla and Karsanti Basins (Fig. 1b) were used to construct subsidence curves, corrected for sediment compaction (Fig. 5), from which several inferences may be drawn.

(i) The Eocene was a period of low net subsidence, except in the Ulukişla Basin. The Early Oligocene was marked by a hiatus in the Ecemiş and Ulukișla Basins. During the Late Oligocene-Early Miocene the Ecemiş, Ulukişla and Karsanti Basins experienced maximum subsidence rates. A significant 'step' is seen at this stage, especially in the Ecemiş profile. Possible explanations are: (i) extensional subsidence or (ii) strike-slip basin formation/transtension. Pure extension is unlikely as the Ecemiş curve does not conform to the characteristic concave shape associated with a rift basin, but is characteristic of a strike-slip basin (Turner 1996).

(ii) The Ecemiş Fault Zone perhaps existed as a localized transtensional basin with a significant normal component during Late Oligocene-Early Miocene time. Coeval top-to-thesouth detachment faulting along the southern edge of the Niğde Massif (Whitney \& Dilek 1997) was then bounded laterally by the Ecemiş Fault Zone, beyond which (present east) less exhumation took place in the Aladağ Mountains. However, this process did not operate along the entire present 

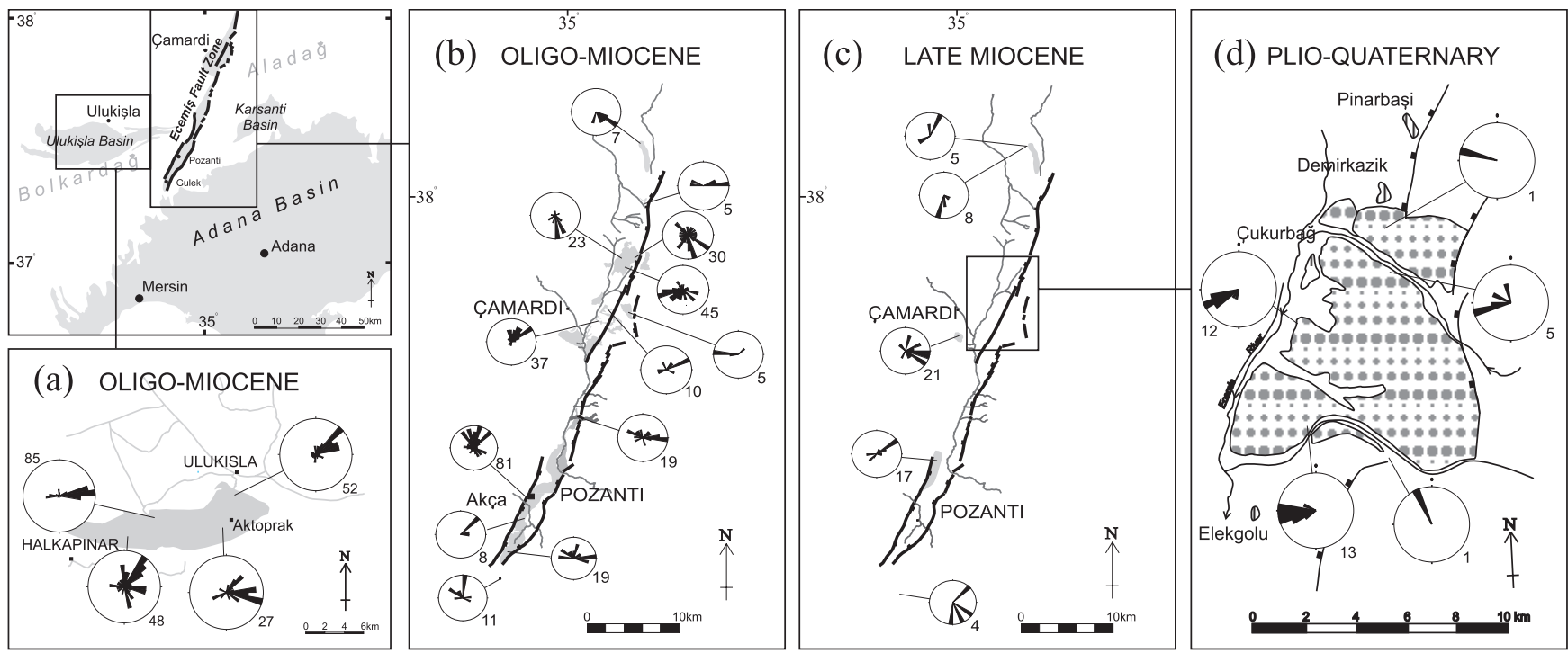

Fig. 4. Palaeocurrent data from (a) Oligocene to Early Miocene red-bed unit within the Ecemiş Fault Zone, (b) Late Miocene unit within the Ecemiş Fault Zone and (c) Plio-Quaternary sediments from the Çamardi fan complex. Subscripts indicate number of data points. Palaeocurrent indicators used include: (i) orientations of avalanche faces on asymmetrical ripples, (ii) groove marks, (iii) prod marks and (iv) alignment of the long (c) axis of pebbles.

length $(c .100 \mathrm{~km})$ of the Ecemiș Fault Zone and probably preceded through-going strike-slip.

(iii) The Late Miocene then saw a slowing of subsidence in the Ecemiş and Ulukişla basins, while subsidence rates in the Adana Basin increased. The Pliocene and Early Quaternary period was marked by a second phase of inferred subsidence in the Ecemiş area, which is again compatible with transtension.

\section{Deformation history}

Three main deformation phases are recognized, as follows.

\section{Late Cretaceous}

Pervasive SE- to SSE-vergent folding and thrust faulting are observed within Mesozoic carbonate platform units forming the Bolkardağ and Aladağ Mountains on either side of the Ecemiş Fault Zone (Fig. 6a), associated with southward emplacement of a regionally extensive ophiolite during latest Cretaceous time (Lytwyn \& Casey 1995; Dilek et al. 1999). On the western side of the Ecemiş Fault Zone SE- to SSE-vergent folding and thrusting are well exposed in the Pozanti and Tekir areas (Fig. 6a), as also noted by Koçyiğit \& Beyhan (1998) (location $X^{\prime}$ on their fig. 9). On the eastern side of the Ecemiş Fault Zone, similar SE-directed folding and thrusting are observed beneath the Pozanti-Karsanti (Aladağ) ophiolite and localized metamorphic sole (Fig. 3) at both Madenboğazi in the north and Hamidiye in the south (Fig. 6a). The upper age of this thrusting is constrained by undeformed latest Cretaceous sediments unconformably overlying the ophiolite and related melange, both west and east of Pozanti (Demirtaşli et al. 1984; Ünlügenç 1993).

\section{Late Eocene}

NW-directed thrusting and folding are seen within the Mesozoic platform carbonate rocks on both sides of the Ecemiş Fault Zone. This deformation resulted in spectacular

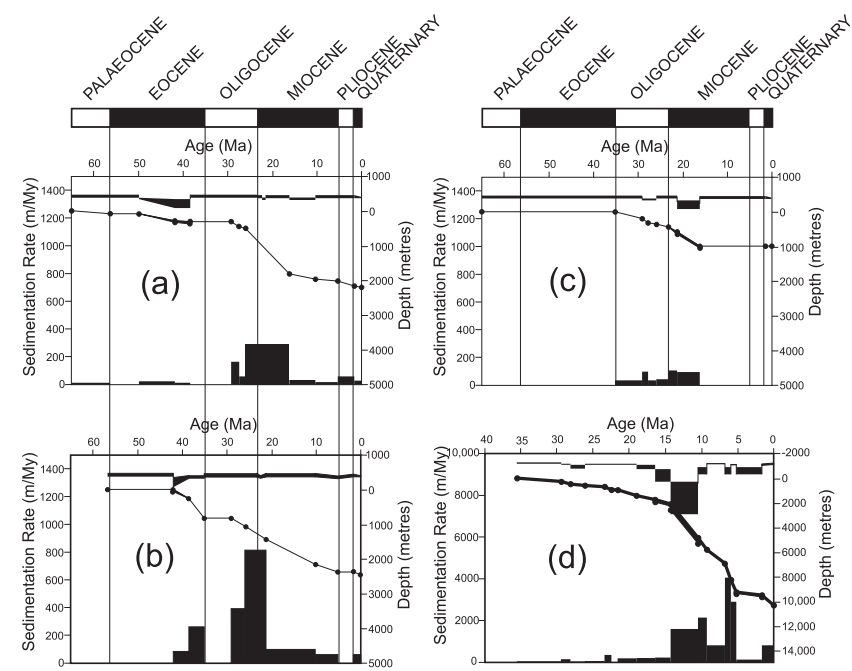

Fig. 5. Subsidence history plots generated from composite logs in four basins (see Fig. 1b for basin locations). (a) Ecemiș Fault Zone composite log, (b) Ulukișla Basin composite log, (c) Karsanti Basin composite log and (d) Adana Basin composite log. The OligoMiocene unit of the Ecemiş Fault Zone has poor time constraints, thus curves should be seen as rough indicators of rapid vs. slow sedimentation and subsidence. Total decompaction subsidence was calculated using the approach of Steckler \& Watts (1978). The stratigraphic section preserved at each site was split up into a number of layers, dated using published foraminiferal or ostracod biostratigraphy. Each of these layers was removed to reconstruct the total subsidence history of the site, and remaining layers were decompacted using standard porosity-depth relationships determined by Sclater \& Christie (1980). Water depths of deposition were estimated using facies and trace fossil evidence and all curves were plotted using the timescale of Harland et al. (1989). Data displayed include sedimentation rates (lower bar scale), depth to basin floor (central line graph) and inferred fluctuations in water depth (upper bar scale). Single line indicates subsidence without water depth correction; shaded area is subsidence with minimum and maximum water depth corrections. 

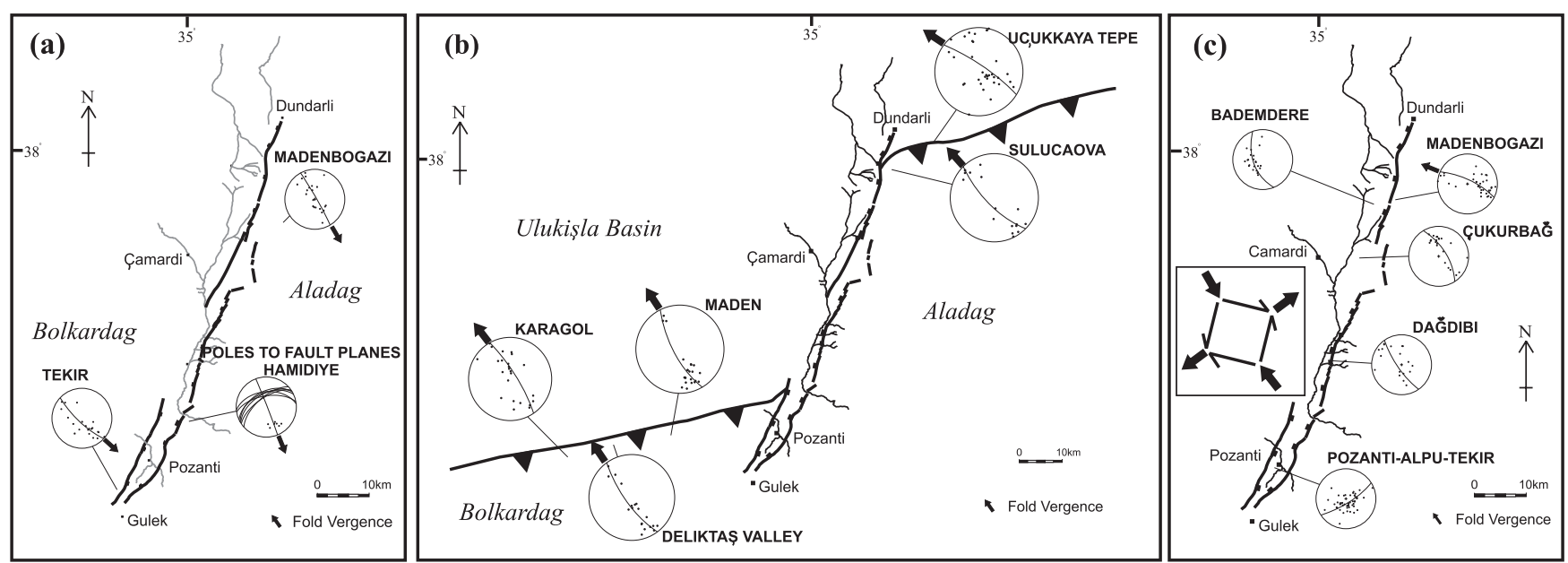

Fig. 6. The three main deformation phases of the Ecemiş area: (a) Late Cretaceous deformation of Mesozoic carbonates during ophiolite emplacement, (b) Late Eocene folding/thrusting and (c) Mid-Miocene compression and folding. Stereoplots show poles to bedding planes (dots), fold profile planes (great circles) and fold vergence (solid arrow). Thrust faults are shown by triangles on the overriding plate.
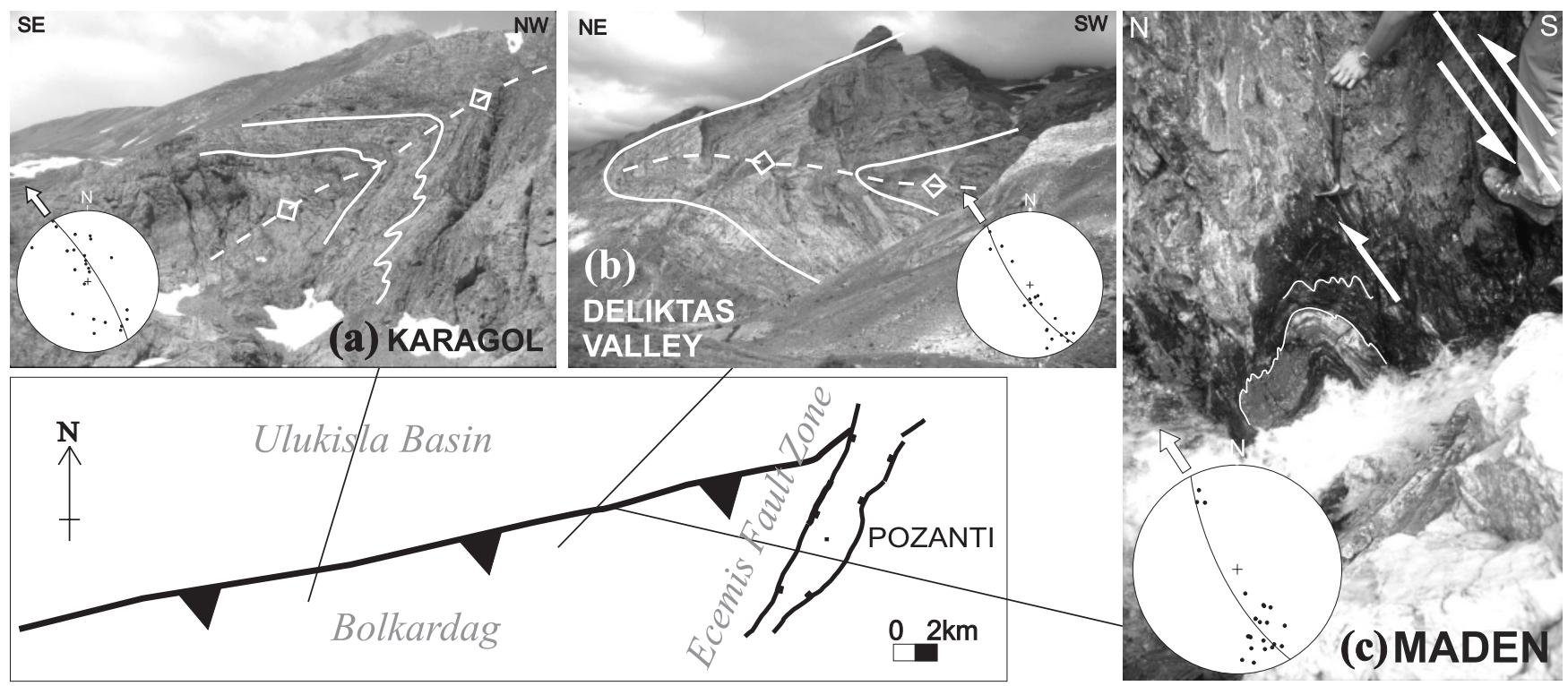

Fig. 7. Photographs of the Bolkar north-directed fold and thrust system. (a) North-vergent recumbent folding at Karagöl, (b) north-vergent recumbent folding at Deliktaș Valley (1 km SW of Maden village), (c) north-vergent thrust fault contact at Maden village with associated ductile deformation.

mountain-scale recumbent folds above a major NW-directed thrust fault, localized along the northern margin of the Bolkardağ (e.g. at Maden village, Deliktaş and Karagöl); folding tightens significantly from east to west (Figs $6 \mathrm{~b} \& 7$ ).

A Late Eocene age is assigned to this deformation phase as: (i) Oligocene sediments are reported to onlap unconformably onto the Bolkar thrust at Maden village (Demirtaşli et al. 1984) and (ii) the Eocene sediments in the Ulukişla basin, tightly folded in the same sense as the Bolkar thrust, are Eocene in age (Demirtaşli et al. 1984; Oktay 1982). Overlying Oligocene sediments in the same basin are not similarly deformed.

Folding and thrust faulting with a similar sense are also seen on the eastern side of the Ecemiş Fault Zone, at Sulucaova village and Uçukkaya Tepe (Tekeli et al. 1984; Fig. 6b). A Late Eocene age is tentatively assigned to these structures, as coeval carbonates within the Aladağ Mountains (at Sulucaova village and Uçukkaya Tepe) are deformed in a similar fashion to the adjacent Bolkar thrust further west. However, the deformation of Oligo-Miocene rocks of the Ecemiş Fault Zone is very different (i.e. fold profile planes have different orientations).

The Late Eocene north-directed thrust is part of a regional collisional deformation which affects the Tauride Mountains as a whole, including the final emplacement of the Alihoca and Kiziltepe ophiolites in the Bolkar Mountains (Dilek \& Whitney 1997) and units further west, including the BeyșehirHoyran-Hadim Nappes (Ozgül 1984; Monod 1977) and the Lycian Nappes (Collins \& Robertson 1998). It is generally accepted that final closure of a Neotethyan oceanic basin to the north of the Tauride carbonate platforms took place during Late Eocene time (Șengör \& Yilmaz 1981; Robertson \& Dixon 1984). 


\section{Mid-Miocene}

The Late Oligocene-Early Miocene red-bed succession within the Ecemiş Fault Zone is significantly deformed compared to the overlying, relatively flat-lying Late Miocene succession, and an angular unconformity between them exists at a number of localities along the Ecemiş Fault Zone (Fig. 2). Plots of poles to bedding (Fig. 6c) display profile planes with a roughly NW-SE strike, indicating NW-SE compression. This is not the case in the south where NE-SW striking profile planes predominate. This deformation also affects rocks of similar age in the adjacent Ulukişla and Karsanti Basins; however, it is most intense closest to the present Ecemiş Fault Zone scarps (e.g. in exposures beneath the Çamardi alluvial fan complex). We infer that this deformation took place in Mid-Miocene time during a hiatus in sedimentation, and does not reflect a phase of ENE-directed compression of the entire OligoceneMiocene succession throughout the Ecemiş Fault Zone, as proposed by Koçyiğit \& Beyhan (1999).

Assuming strike-slip was already active during the MidMiocene (as suggested by subsidence data) then NW-SE compression could be accommodated by sinistral strike-slip and local transpression (inset Fig. 6c), removing any need to invoke a large-scale reversal of slip direction on the Ecemiş Fault Zone during the Mid-Miocene (Koçyiğit \& Beyhan 1999), which is not supported by slickenline evidence (see below). The localized change in compression orientation in the south could be due to a change in stress regime as the fault zone approaches a bend in its regional trend (the 'Namrun segment bend' of Koçyiğit \& Beyhan 1998; Fig. 1b). The regional cause of Mid-Miocene NW-SE compression was probably related to 'collisional' tectonics in SE Anatolia (Șengör et al. 1985; Dewey et al. 1986).

\section{Fault orientation and slickenlines}

Slip plane and slickenline orientations were documented from rock units of the following ages: Mid-Eocene, Late OligoceneEarly Miocene, Late Miocene and Plio-Quaternary (Fig. 8). Slickenline population in rocks of any given age may be overprinted by any younger faulting. However, a comparison of the slickenline population in rocks of different ages is informative.

Plio-Quaternary alluvial fan units (Fig. 8) show a well grouped array of NNE-SSW-striking faults with exclusively normal offsets. Faults affecting this unit are inferred to be of Pliocene-Quaternary age.

Late Miocene units (Fig. 8) display a high proportion of normal faults with a similar NNE-SSW strike, mainly in the southern part of the area. Well clustered sinistral faulting with a NE-SW strike is dominant in the north. Both normal and sinistral slip-face populations are sub-parallel to the present Ecemiş Fault Zone. Dextral faulting with an ESE-WNW strike is also significant. Faults affecting this unit are inferred to be of latest Miocene age and younger.

Slip faces within the Oligo-Miocene red-bed unit (Fig. 8) conform to a pattern of dominantly NNE-SSW striking normal faults and well clustered north-south striking sinistral faults. This pattern also includes a component of east-west striking normal faults in the south of the area, not seen in younger rocks. Reverse faults display transport toward the NW, and poles to dextral faults do not display any coherent pattern. Faults affecting this unit are inferred to be of MidMiocene age and younger.
The Eocene exposures (Fig. 8) show different fault patterns. East of the Ecemiş Fault Zone (Kaleboynu Tepe), NE-vergent reverse faults are dominant, whereas outcrops to the west of the Ecemiş Fault Zone (Evliya Tepe) are marked by NWvergent reverse faults. Faults affecting this unit are inferred to be of Eocene age and younger.

The majority of slickenlines from the graben walls (Fig. 8) have normal, or sinistral slip with a NNE-SSW fault orientation. As yet there are no constraints on the age of this faulting.

Taking the rock units from youngest to oldest, we infer that faulting during the latest Plio-Quaternary (Fig. 8) was dominated by near east-west extension, whereas faulting during the latest Miocene was dominated by normal and sinistral strikeslip faulting. Strike-slip was most active in the north of the area, but near east-west extension dominated in the south. The localized dextral component (Fig. 8) could be the result of WNW-ESE-striking dextral Riedel shears, compatible with dominant NNE-SSW-striking sinistral faulting.

During the Mid-Miocene (Fig. 8) the normal and sinistral fault pattern was similar to that of the latest Miocene-Pliocene described above. The data cannot distinguish whether this NNE-SSW-striking normal and sinistral fault pattern is the result of (a) more recent latest Miocene-Pliocene overprinting, or (b) continuous normal and sinistral faulting from MidMiocene until the Pliocene. An additional set of east-west striking normal faults was active during this period, concentrated in the south. These faults are in the wrong orientation to be tensional fractures associated with NNE-SSW sinistral faulting (NW-SE striking); they may, however, be associated with Late Oligocene-Early Miocene normal faulting which accommodated north-south extension in this area.

Data from Eocene units (Fig. 8) are limited and possibly overprinted such that little meaningful interpretation can be made.

The graben-wall scarp exposures (Fig. 8) are also difficult to interpret, having little age constraint. However, we see these as recording relatively recent faulting, as they often display overprinted slickenlines from several fault phases. These data suggest a recent history of predominantly sinistral transtension, with normal and sinistral slickenlines predominating.

From the slickenline data presented here we conclude that faulting (normal or strike-slip) has been active as late as the Quaternary along the Ecemiş Fault Zone and was also active during the Miocene and possibly earlier. We, therefore, cannot support the views of Yetiş (1984) and Westaway (1999) that significant strike-slip faulting ceased on the Ecemiş Fault Zone by the end of the Eocene.

\section{Geomorphology}

Two opposing hypotheses are: (i) that the current geomorphology is the result of active strike-slip faulting (Koçyiğit \& Beyhan 1998, 1999) or (ii) the result of the glacial scouring of an ancient fault zone which was last active during the Eocene (Westaway 1999). In the key Çamardi area in the centre-north of the Ecemiş Fault Zone (Fig. 9), Plio-Quaternary alluvial fans are well developed, fault scarps are at their highest and exposures provide evidence for active strike-slip, as follows.

(i) The Ecemiș Fault Zone crops out as a deep (50-1200 m elevation difference) graben and half graben along its course (Fig. 1b). This topographic depression is more pronounced than any other north-south feature cutting across the Tauride 


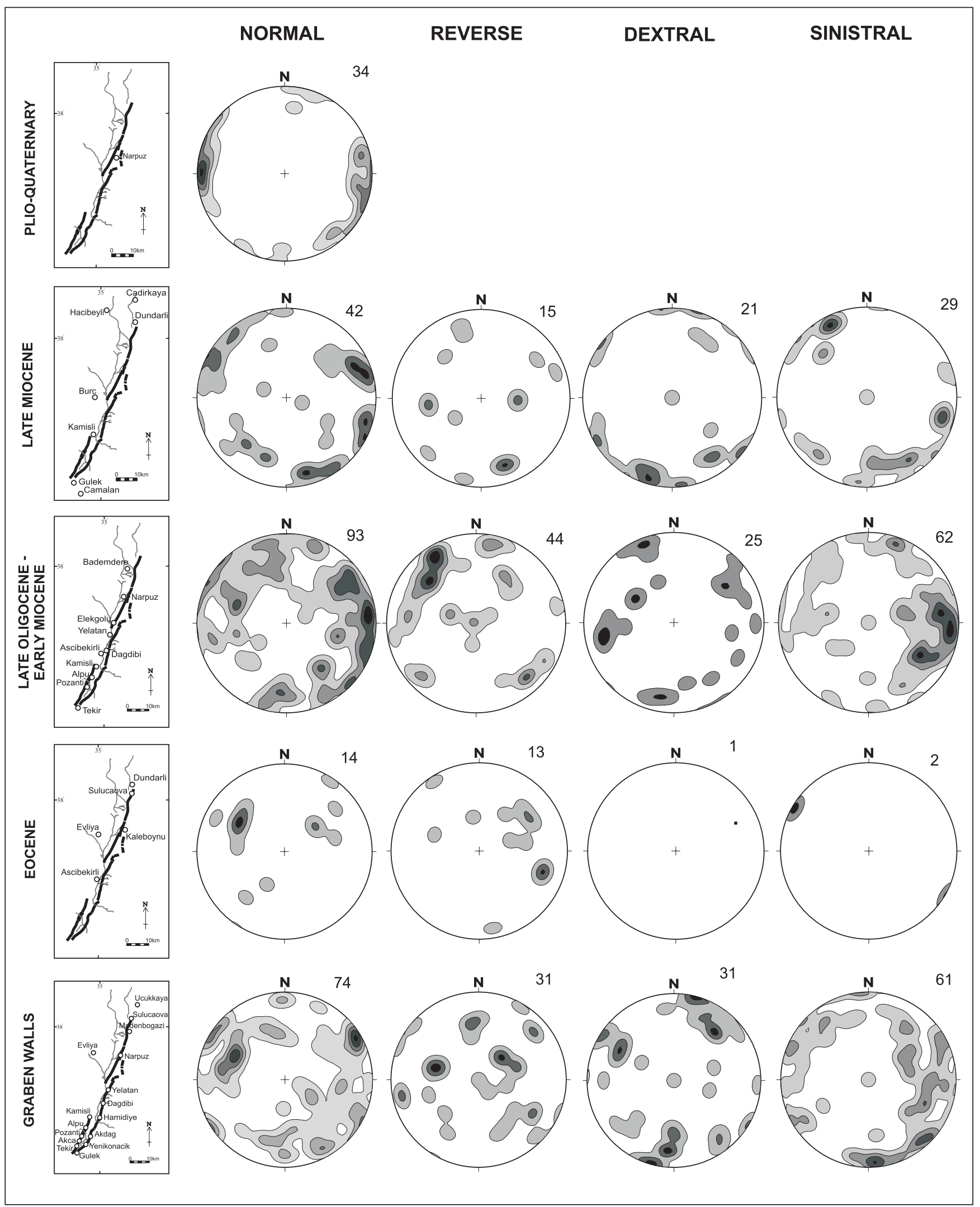

Fig. 8. Fault data from the Ecemiş Fault Zone separated by age of unit studied. Data presented as map of dataset localities and contoured poles to fault planes, separated by dominant slip sense (calculated from plucking on slickenlines and measured bed offsets). Superscripts indicate number of faults in dataset. 


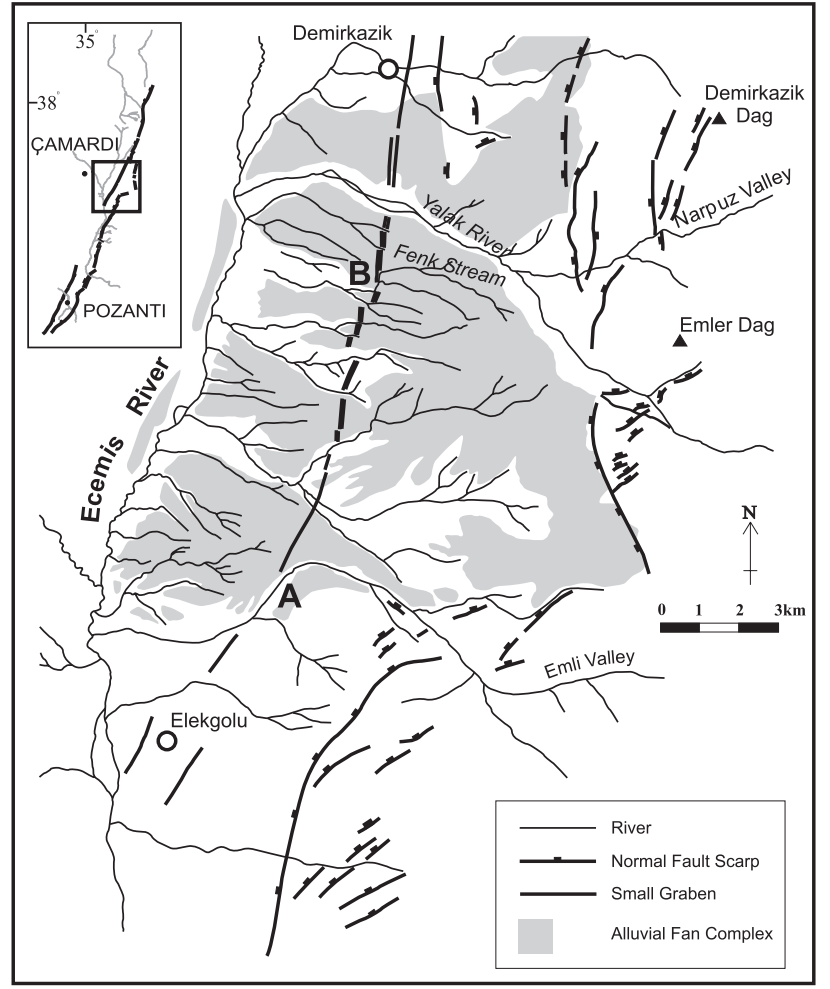

Fig. 9. Map of the Çamardi fan area made from tracings of 1:30 000 aerial photographs and field mapping. Map shows drainage (thin lines), Plio-Quaternary alluvial fan complex (shaded area), main fault scarps (black lines with block symbol on downthrown side) and the 'small graben' feature (thick black line). (a) Emli Valley, (b) Fenk stream on alluvial fan surface.

Mountains in the region. The graben and half graben are bounded by significant fault scarps, which bring Mesozoic and Palaeozoic platform carbonates into contact with Tertiary sediments.

(ii) Segments of the main fault scarp are arranged in an en echelon pattern, stepping systematically to the left into the hanging wall, resulting in formation of relay zones at stepovers (Fig. 9). Such relay zones in this area coincide with the passage of major streams from east to west, draining the Aladağ Mountains in the uplifted footwall. Examples of this can be seen at Narpuz Valley and Maden gorge where these streams pass through the main scarp (Fig. 9).

(iii) A large alluvial fan complex is seen to the west of the main fault scarp. Similar fans occur along the length of the fault zone, but they are thickest and best preserved in the Çamardi and Alpu/Pozanti areas (Fig. 9).

(iv) This fan has been repeatedly incised to form multiple erosional terraces along currently active river courses. This is best seen along the Yalak river, $2 \mathrm{~km}$ south of Demirkazik village (Fig. 9), where at least four river terraces are visible at different levels. We attribute these terraces to fluvio-glacial discharge, reflecting fluctuations in glacial meltwater issuing from the Aladağ. The terraces also represent progressive downcutting within the Ecemiş Fault Zone during the Pleistocene under the dominant influence of climatic change (i.e. glacial-interglacial cycles), albeit during longer term regional uplift. Regional fluvial downcutting and headward erosion are documented throughout the Taurus Mountains during Plio-Quaternary time (Erol 1991; Glover \& Robertson $1998 a)$. (v) The Çamardi fan complex is dissected by a 'small graben' (Fig. 9) that, as noted by Koçyiğit \& Beyhan (1999), is inferred to mark the site of surface breaks induced by historical earthquakes. This feature is dextrally offset numerous times (apparently by east-west-striking faults), with offsets in the order of hundreds of metres. This could reflect late-stage (possibly currently active) block rotations within a larger sinistral strike-slip system (Garfunkel 1989).

(vi) Diversion of active stream courses is seen along exposed faults. Maximum stream diversions have been measured on the 'small graben' from aerial photographs and in the field. These include the Emli Valley with $2.4 \mathrm{~km}$ of sinistral offset (Fig. 9, point A) and the Fenk stream at the 'small graben' with $750 \mathrm{~m}$ of sinistral offset (Fig. 9, point B). River diversions at the main scarp are relatively small $(<250 \mathrm{~m})$, however. We, therefore, propose that the most recent strike-slip has focused on this 'small graben'.

(vii) The upper valleys of the Aladağ Mountains are classically U-shaped, with extensive accumulations of unconsolidated terminal and lateral glacial moraines (e.g. upper Emli valley and Narpuz valley, Fig. 9), indicating mountain glaciation during the Pleistocene. The alluvial fans and incised terraces of the main Ecemiş Fault Zone are formed of wellcemented (pre-Quaternary) material and are interpreted as pre-glacial maximum in age (i.e. Late Pleistocene-Holocene). These fans do not appear to have been overridden by glaciers; also the main fault zone is devoid of moraine-like accumulations, both suggesting that the main Ecemiş Fault Zone was not the site of extensive glaciation, contrary to Westaway (1999).

From the above field observations we conclude that a small amount of strike-slip (up to $250 \mathrm{~m}$ ) has occurred since the deposition of the Plio-Quaternary fans. However, this was subordinate to coeval dip-slip faulting.

\section{Discussion}

\section{Total offset and published piercing points}

Yetiş (1984) proposed that the majority of strike slip offset on the Ecemiş Fault Zone occurred before Lutetian time (i.e. during the Early Eocene), with minor strike-slip and normal offset during Quaternary time. His argument was based on the dissimilarity of the pre-Eocene stratigraphies in the Çamardi area to the east and west of the Ecemiş Fault Zone compared to younger sediments, and the apparent lack of offset of adjacent Lutetian (Middle Eocene) to Recent deposits in the same area. Yetiş (1978) inferred $80 \pm 10 \mathrm{~km}$ of total sinistral offset during the Early Eocene by indirectly correlating the Pozanti-Karsanti ophiolite to the east of the Ecemiş Fault Zone with the Mersin ophiolite to the SW (Fig. 3). However, even if it is accepted that the Late Cretaceous PozantiKarsanti ophiolite (Lytwyn \& Casey 1995) and the Mersin ophiolite (Parlak \& Delaloye 1996) were emplaced in latest Cretaceous time as a single 'continuous ophiolite complex' (Dilek \& Moores 1990; Dilek \& Whitney 1997), which is debatable, the apparent offset of ophiolite outcrops on either side of the fault zone (Fig. 3) could reflect Tertiary differential uplift and erosion rather than strike-slip offset. Outliers of the Pozanti-Karsanti ophiolite occur as thrusted horses as far north as Madenboğazı (Fig. 3) where they are imbricated with Mesozoic platform carbonates by south-directed thrusting, further questioning a simple correlation of the large ophiolitic bodies across the Ecemiş Fault Zone. 


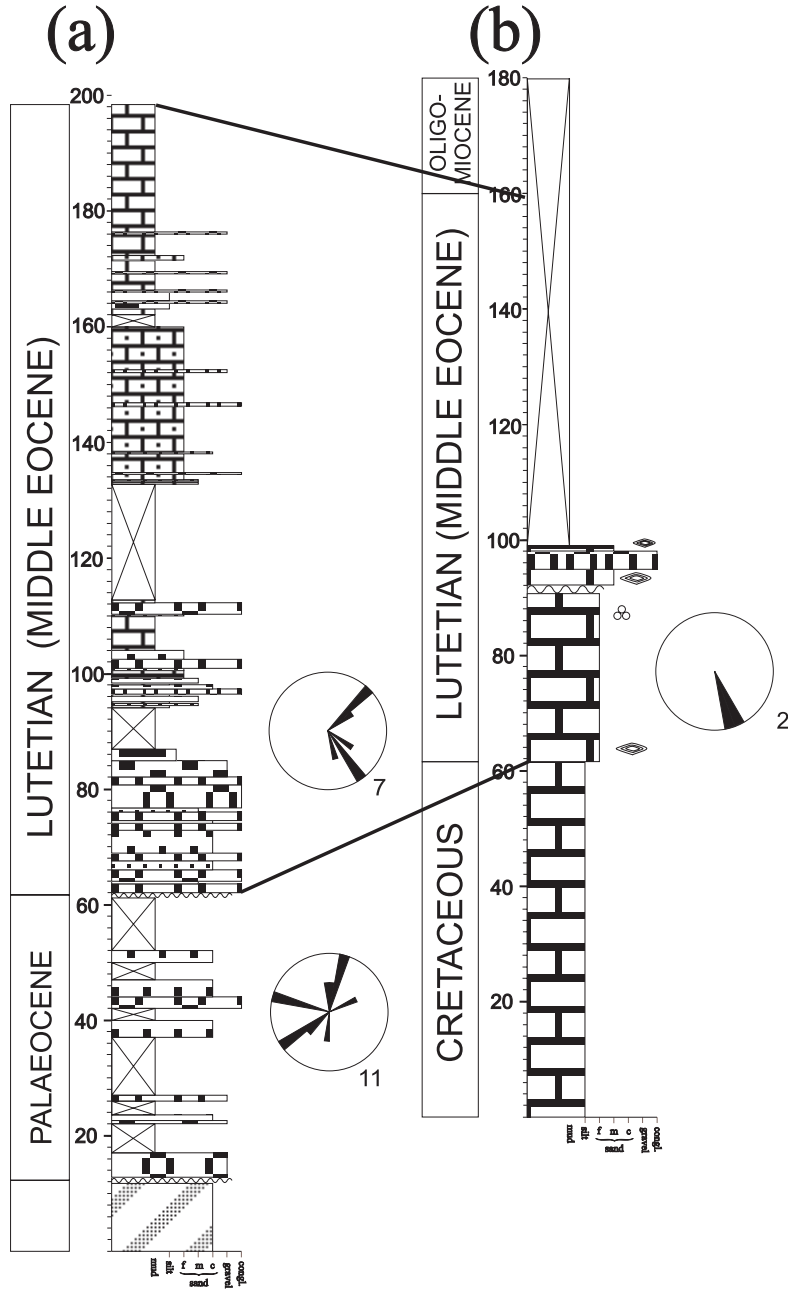

Fig. 10. Summary sedimentary logs of two Lutetian (Mid-Eocene) outcrops in the Çamardi area. (a) Evliya Tepe succession;

(b) Kaleboynu Tepe succession.

Detailed sedimentary logging has revealed that the Lutetian (Middle Eocene) outcrops on either side of the Ecemiş Fault Zone, correlated by Yetiş (1984), as effectively sealing earlier strike-slip displacement in reality display very different depositional facies, palaeocurrents and deformational styles
(Fig. 10). The western Evliya Tepe exposure (Figs 3 \& 10) displays basal high-energy submarine debris flows, passing upwards into lower energy clastic and micritic limestone beds, interpreted as a shallow-water deltaic environment. This exposure displays palaeoflow (determined from cross lamination and groove casts) towards the NE and SE, and west-vergent folding and thrust faulting. By contrast the eastern Kaleboynu Tepe exposure (Figs 3 \& 10) displays a succession of increasing depositional energy, passing from sub-wave-base shelf micrites into high-energy terrestrial clastic debris flows. Palaeoflow is towards the SSE and the outcrop displays NE-vergent thrust faulting, but no folding. If the outcrops had remained adjacent since Mid-Eocene time then such widely divergent sedimentary and structural signatures would not be expected over a distance of $10 \mathrm{~km}$. Instead, the two outcrops probably originated further apart and underwent separate depositional and strain histories prior to final strike-slip juxtaposition.

To determine the amount of strike-slip offset, Koçyiğit \& Beyhan (1998) proposed as a piercing point a south-directed thrust fault exposing Permian over Triassic rocks on both sides of the Ecemiş Fault Zone, implying a total sinistral offset of $74 \mathrm{~km}$. During this study the proposed piercing points were examined in detail (Table 2 and Fig. 11). The site at Tekir (west side of Ecemiş Fault Zone, Fig. 11b) closely matches the description of Koçyiğit \& Beyhan (1998). However, their description of the eastern piercing point is less precise, allowing two possible localities, i.e. Upper Madenboğazı (Fig. 11c) and Uçukkaya Tepe (Fig. 11d) to be considered as the eastern piercing point (see Table 2 for comparison). Neither of these candidates were found to correlate well with the Tekir site in the west, having different thrust fault geometries, kinematics and rocks in the hanging-and footwalls. The piercing points proposed by Koçyiğit \& Beyhan (1998) are, thus, unreliable.

\section{New piercing points}

A candidate for new structural piercing points is provided by the Bolkar thrust and fold system (Figs 6b, 7 \& 11d). Late Eocene overturned folds and thrusts crop out on both sides of the fault zone, marking the northern margin of the Bolkar Mountains to the west of the Ecemiş Fault Zone (mapped by Demirtaşli et al. 1984), and also to the east on Uçukkaya Tepe, NE of Sulucaova (mapped by Tekeli et al. 1984). Outcrops on both sides of the Ecemiş Fault Zone exhibit: (a)

Table 2. Results of the field examination of piercing points proposed by Koçyiğit \& Beyhan (1998)

\begin{tabular}{|c|c|c|c|}
\hline & Tekir (Fig. 11b) & $\begin{array}{l}\text { Upper Madenboğazı, east of } \\
\text { Pınarbası (Fig. 11c) }\end{array}$ & $\begin{array}{l}\text { Uçukkaya Tepe, east of } \\
\text { Sulucaova (Fig. 11d) }\end{array}$ \\
\hline Tectonic transport direction & To south & To south & To north \\
\hline Nature of thrust & Simple flat plane thrust & Downward facing thrusted nappe & Simple flat plane thrust \\
\hline Nature of folding & $\begin{array}{l}\text { Tight overturned folds in footwall } \\
\text { and hanging wall }\end{array}$ & $\begin{array}{l}\text { Open folding in both footwall and } \\
\text { hanging wall-no overturning }\end{array}$ & $\begin{array}{l}\text { Tight overturned folds in both } \\
\text { footwall and hanging wall }\end{array}$ \\
\hline Footwall lithology & $\begin{array}{l}\text { Unmetamorphosed limestones. } \\
\text { Triassic (Koçyiğit \& Beyhan 1998) }\end{array}$ & $\begin{array}{l}\text { Limestones with bauxite stringers. } \\
\text { Triassic-Jurassic Beyaz Alada Fm } \\
\text { (Tekeli 1984) }\end{array}$ & $\begin{array}{l}\text { Low-grade metamorphosed } \\
\text { limestones. Permian-Triassic } \\
\text { Yahyali Gp. (Tekeli 1984) }\end{array}$ \\
\hline Presence of ophiolite? & No ophiolite involved & $\begin{array}{l}\text { Ophiolite slivers exposed in } \\
\text { footwall }\end{array}$ & $\begin{array}{l}\text { Ophiolite exposed in local } \\
\text { footwall }\end{array}$ \\
\hline
\end{tabular}



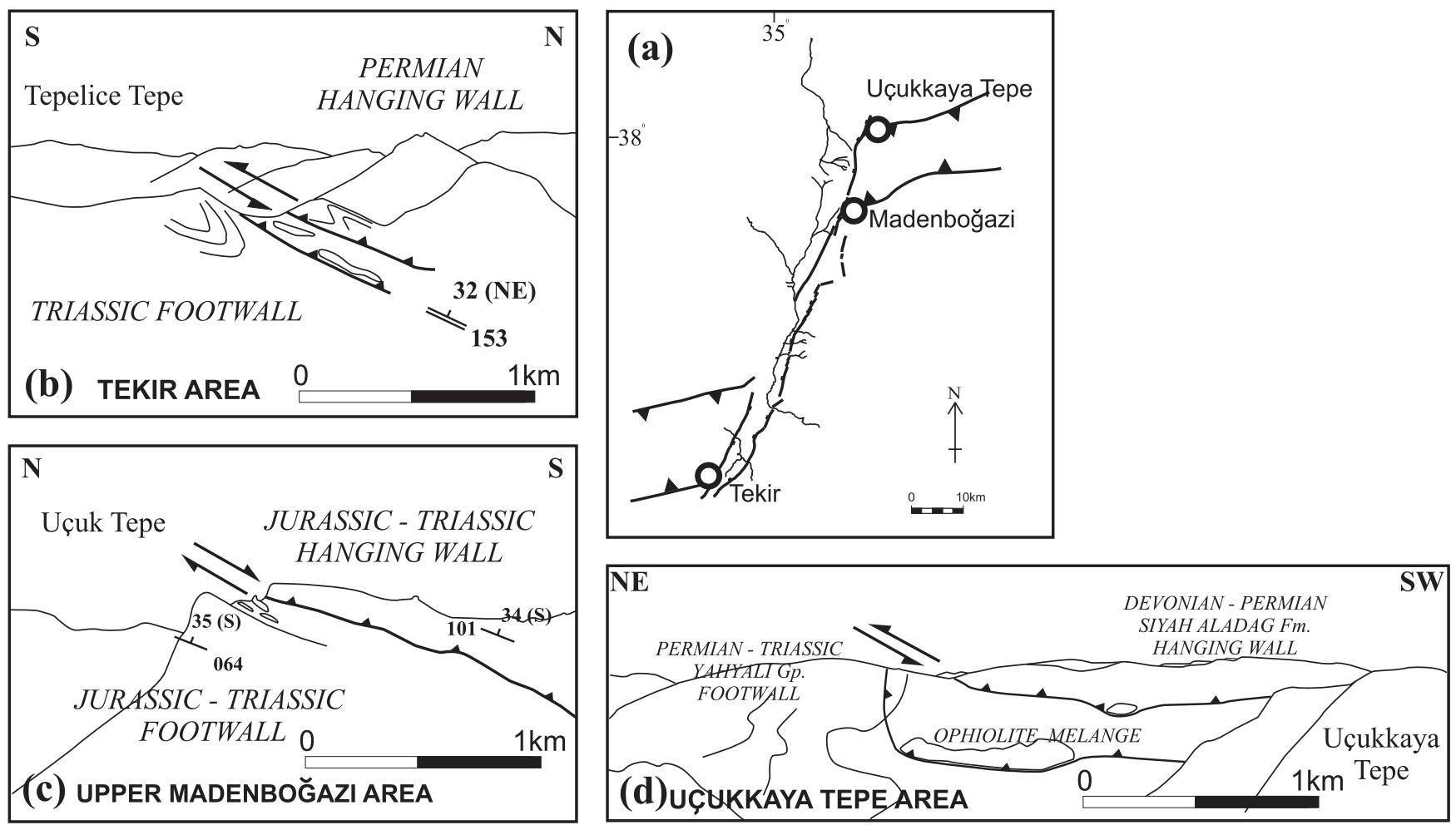

Fig. 11. Sketches of possible sites for Koçyiğit \& Beyhan's (1998) piercing points. (d) Map of the Ecemiş Fault Zone shows position of: (a) western piercing point at Tekir, a north-dipping south-directed thrust fault, (b) south-dipping, south-directed deformed thrust fault at Madenboğazı (as seen from the west), (c) south-dipping, north-directed thrust fault at Uçukkaya Tepe, Sulucaova. Table 2 compares characteristics of each piercing point candidate.

NW-SE-striking fold profile planes (Fig. 6b), (b) SSE-dipping thrust fault geometries, (c) thrust faults dipping at an angle of $40-50^{\circ}$, (d) consistent NW-directed kinematic indicators (fold vergence, Fig. 7), (e) similar Late Triassic-Early Jurassic Mesozoic platform carbonates in the hanging wall and (f) overturned fold axial planes in thrust hanging walls and footwalls. Acceptance of the above piercing points yields a total sinistral offset of $60 \pm 5 \mathrm{~km}$ since the Late Eocene.

However, we foresee three potential difficulties with our proposed new piercing points. Firstly, different rocks are present in the thrust footwall to the east and west of the Ecemiş Fault Zone. This is mainly due to the presence of Quaternary east-west-striking (down to north) normal faulting along the line of the Late Eocene north-directed Bolkar thrust (Dilek \& Whitney in press). Normal faults are well developed to the west, but not to the east of the Ecemiş Fault Zone. As a result of this normal faulting, in the west the Eocene thrust footwall rocks have been down-thrown to the north and buried beneath sediments of the Late Cenozoic Aktoprak Basin, the upper part of the Ulukişla Basin (Fig. 1b). By contrast, to the east of the Ecemiş Fault Zone the inferred continuation of the Bolkar thrust remains unaffected by more recent normal faulting.

The second potential problem is that the two correlated thrust zones might originally have existed at different structural levels during the Late Eocene, as suggested by the higher metamorphic grade to the west than the east of the Ecemiş Fault Zone (Demirtaşli et al. 1984), the two only being brought to the same level later by differential movement across the fault zone. However, the high angle of the thrusting $\left(40-50^{\circ}\right)$ reduces errors associated with correlating thrusts of originally different structural levels. For example, an original vertical separation of $1 \mathrm{~km}$ would result in only a small horizontal separation of $1.3-1.5 \mathrm{~km}$.

The third potential problem is that the Mesozoic palaeogeography and Late Cretaceous-Early Tertiary deformation of the Bolkardağ and Aladağ carbonate platforms on either side of the Ecemiş Fault Zone may have been different. For example, the Ecemiş Fault Zone might have reactivated a long-lived structural lineament offsetting the Tauride microcontinent during the Mesozoic. However, at present we adopt the simplest hypothesis, that the two platform units shared a linear (east-west) northern margin during the Mesozoic and underwent a similar deformation history thereafter.

\section{Regional palaeomagnetic and GPS Data}

Tatar et al. (1996) sampled Eocene volcanics from Central Turkey (Yozgat area, Fig. 1a) and found an average regional anticlockwise vertical-axis rotation of $c .33^{\circ}$ since the Eocene. They conclude that most of this rotation occurred during the Quaternary. Tatar et al. (2000) sampled 1-2 Ma lava flows from the Erçiyes Basin within the Ecemiş Fault Zone (Fig. 1a), $20 \mathrm{~km}$ north of the area studied. They found that anticlockwise rotation of $10^{\circ}$ has occurred within the last $1 \mathrm{Ma}$. Also, Gürsoy et al. (1996) sampled the Sivas Basin (northern part of the Central Anatolian Fault Zone of Koçyiğit \& Beyhan 1998; Fig. 1a) and proposed regional anticlockwise rotation during the Quaternary, at an average rate of $10^{\circ} \mathrm{Ma}^{-1}$.

In addition, the rates of present-day instantaneous crustal movement have been measured using GPS stations throughout Turkey (Reilinger et al. 1997). By measuring absolute movements between 1988 and 1994 they conclude that central 
and eastern Anatolia are currently undergoing westward extrusion and anticlockwise vertical axis rotation bounded by the North and East Anatolian Faults. The above considerations lead to the following conclusions regarding the regional tectonic setting.

\section{Conclusions}

(1) The Ecemiş Fault Zone is a regionally important transtensional lineament with an inferred total of $60 \pm 5 \mathrm{~km}$ sinistral offset since Late Eocene time. This offset is comparable with that of the North Anatolian Fault Zone (c. $100 \mathrm{~km})$, but larger than that of the East Anatolian Fault zone (18-22 km).

(2) Strike-slip faulting along the Ecemiş Fault Zone probably began in the Mid-Miocene or slightly earlier, as suggested by subsidence analysis, at least 7-10 Ma earlier than initiation of the North Anatolian Fault Zone and the East Anatolian Fault Zone. The early history (Mid-Late Miocene) of the Ecemiş Fault Zone was dominated by sinistral strike-slip, whereas the later history (Pliocene and Quaternary) was dominated by east-west extension, with a very much smaller component of strike slip.

(3) The Ecemiş Fault Zone experienced a prolonged tectonic history. In the study area it lay within a transtensional basin during Oligo-Miocene time, accommodating differential alongstrike exhumation of the Taurus Mountains. The Ecemiş Fault Zone was activate as a through-going left-lateral strike-slip system by Mid-Miocene time, helping to accommodate regional deformation of the orogen, up to $10 \mathrm{Ma}$ prior to Plio-Quaternary westward tectonic escape of Anatolia along the North Anatolian and East Anatolian fault systems. During Plio-Quaternary time, slip became mainly extensional with a minor trans-tensional component, creating grabens and halfgrabens along the Ecemiş Fault Zone. Left-lateral displacement continued into Late Pliocene-Quaternary time, as shown by river offsets on alluvial fans shed from the footwall of the transtensional half-grabens.

(4) During the Late Miocene-Quaternary the Ecemiş Fault Zone apparently rotated to near its current NNE-SSW orientation within encompassing crustal units, as suggested by palaeomagnetic data, thus accommodating progressively more east-west extension and less strike-slip. The present-day sinistral component of extrusion is accommodated by faults with a NE-SW strike (similar in orientation to the East Anatolian Fault Zone). Assuming the Ecemiş Fault Zone rotated away from an initial NE-SW strike, it later ceased to be in the optimum orientation to accommodate strike-slip and instead experienced dominantly normal offset.

(5) Significant internal fault deformation took place within Anatolia prior to the initial stages of westward tectonic escape. Internal deformation was active prior to and during motion on the bounding right-lateral North Anatolian Fault Zone and left-lateral East Anatolian Fault Zone. Internal deformation of Anatolia may, therefore, have proceeded along multiple, rotating, strike-slip zones rather than by simple extrusion of a coherent Anatolian 'microplate' bounded by strike-slip fault to the north and south.

This research was funded by NERC grant number GT04/97/89/ES. The authors would like to thank the staff of Çukurova University, Ananda, especially Ulvican Ünlügenç for scientific discussion and logistical help. Discussions with Ali Koçyiğit and Cengiz Yetiş are also acknowledged. We would like to thank G. Kelling and Y. Dilek for thought-provoking and constructive reviews. We are also grateful to MTA, Ankara for access to aerial photographs.

\section{References}

Çemen, I., GöncüoĞLu, M.C. \& Direk, K. 1999. Structural evolution of the Tuzgölü Basin in Central Anatolia, Turkey. Journal of Geology, 107, 693-706.

Collins, A. \& Robertson, A.H.F. 1998. Processes of Late Cretaceous to Late Miocene episodic thrust-sheet translation in the Lycian Taurides, southwest Turkey. Journal of the Geological Society, London, 155, 759-772.

Demirtaşli, E., Bilgin, A.Z., Erenler, F., Işiklar, S., Sanli, D.Y., Selim, M. \& Turhen, N. 1984. Geology of the Bolkar Mountains. In: Tekeli, O. \& GöncÜOǦLu, M.C. (eds) Proceedings of the International Symposium on the Geology of the Taurus Belt, Ankara, 125-141.

Dewey, J.F., Hempton, M.R., Kidd, W.S.F., SAroglu, F. \& Sengör, A.M.C. 1986. Shortening of continental lithosphere; the neotectonics of Eastern Anatolia-a young collision zone. In: CowARD, M.P. \& RIES, A.C. (eds) Collision Tectonics. Geological Society, London. Special Publications, 19, 3-36.

Dilek, Y. \& Moores, E.M. 1990. Regional tectonics of the eastern Mediterranean ophiolites. In: Malpas, J., Moores, E.M., Panayiotou, A. \& Xenophontos, C. (eds) Ophiolites and ocean crustal analogues. Proceedings of the Troodos Symposium, Nicosia, Cyprus, 295-309.

DileK, Y. \& Whitney, D.L. 1997. Counterclockwise PTt trajectory from the metamorphic sole of a Neo-Tethyan ophiolite (Turkey). Tectonophysics, 280, 295-301.

Dilek, Y. \& Whitney, D.L. in press. Cenozoic crustal evolution in Central Anatolia: Extension, magmatism and landscape development. In: Proceedings of the Third International Conference on the Geology of the Eastern Mediterranean. Geological Survey Department, Nicosia, Cyprus, in press.

Dilek, Y., Thy, P., Hacker, B. \& Grundvig, S. 1999. Structure and petrology of Tauride ophiolites and mafic dike intrusions (Turkey): Implications for the Neo-Tethyan ocean. Geological Society of America, Bulletin, 111, 1192-1216.

Dhont, D., Chorowicz, J., Yurur, T., Froger, J.L., Kose, O. \& GundoĞdu, N. 1988. Emplacement of volcanic vents and geodynamics of Central Anatolia, Turkey. Journal of Vulcanology and Geothermal Research, 85, 33-54.

Erol, O. 1991. Geomorphological evolution of the Taurus Mountains, Turkey. Zeitshrift für Geomorphologie, Neue Folge Supplement, 82, 99-109.

Garfunkel, Z. 1989. Regional deformation by block rotation. In: Kissel, C. \& LAJ, C. (eds) Palaeomagnetic Rotations and Continental Deformation. Kluwer Academic Publishers, 181-208.

Glover, C. \& Robertson, A.H.F. 1998a. Role of extension and uplift in the Plio-Pleistocene evolution of the Aksu Basin, SW Turkey. Journal of the Geological Society, London, 155, 365-387.

Glover, C. \& Robertson, A.H.F. 1998b. Neotectonic intersection of the Aegean and Cyprus tectonic arcs: extensional and strike-slip faulting in the Isparta angle. Tectonophysics, 298, 103-132.

Görür, N., Oktay, F.Y., SEYmen, I. \& ȘEnGör, A.M.C. 1984. Palaeotectonic evolution of the Tuzgölü basin complex, Central Turkey; sedimentary record of a Neo-Tethyan closure. In: Dixon, J.E. \& Robertson, A.H.F. (eds) The Geological Evolution of the Eastern Mediterranean. Geological Society, London. Special Publications, 17, 467-482.

Gürsoy, H., Piper, J.D.A., TAtar, O. \& Temiz, H. 1996. A palaeomagnetic study of the Sivas Basin, central Turkey; Crustal deformation during lateral extrusion of the Anatolian Block. Tectonophysics, 271, 89-105.

Harland, W.B., Armstrong, R.L., Cox, A.V., Craig, L.E., Smith, A.G. \& Smith, D.G. 1990. A geological timescale 1989. Cambridge University Press.

KaredinizLI, L. \& KAZANCI, N. 1993. Lithofacies characteristics of Oligocene-Early Miocene deposits of Pozanti (Adana) area and new comments on strike-slip Ecemiş Fault. In: SuAT, A. (ed.) Erk Jeoloji Simpozуити, Bildirileri, 83-92.

KoÇYıĞit, A. \& BeyHAN, A. 1998. A new intracontinental transcurrent structure: the Central Anatolian Fault Zone, Turkey. Tectonophysics, 284, 317-336.

KoçYiĞIt, A. \& Beyhan, A. 1999. Reply to Rob Westaway's comment on 'A new intracontinental transcurrent structure: the Central Anatolian Fault Zone, Turkey'. Tectonophysics, 814, 481-496.

LyTWYN, J.N. \& CASEY, J.F. 1995. The geochemistry of post-kinematic mafic swarms and sub-ophiolitic metabasites, Pozanti-Karsanti ophiolite, Turkey; Evidence for ridge subduction. GSA Bulletin, 107, 830-850.

Monod, O. 1977. Récherches géologique dans les Taurus occidental au sud de Beyşsehir (Türquie). PhD Thesis. Université de Paris-Sud, Orsay, France.

NAZIK, A. \& GöKÇEN, N. 1992. Ostracoda genus Zonocypris and its species in Kurtulmustepe Formation of Ulukişla Basin (Turkey). Revista Espanola De Micropalaeontologia, 24, 63-69. 
OKTaY, F.Y. 1982. Stratigraphy and geological evolution of Ulukişla and its surroundings. Bulletin of the Geological Society of Turkey, 25, 15-23, [in Turkish with English abstract].

OzGüL, N. 1984. Stratigraphy and tectonic evolution of the central Taurus. In: Tekeli, O. \& GönCüOGLu, M.C. (eds) Geology of the Taurus Belt: Ankara, Turkey. MTA, Ankara, 77-90.

ÖZüPEK, S. \& ÇEVIK, L. 1962. Harita Genel Müdürlügü Matbaasinda basilmiştir. Adana regional geological map (1:500,000). Printed by Turkish Geological Survey, Ankara.

Parlak, O. \& Delaloye, M. 1996. Geochemistry and timing of postmetamorphic dyke emplacement in the Mersin Ophiolite (southern Turkey) New age constraints from ${ }^{40} \mathrm{Ar} /{ }^{39} \mathrm{Ar}$ geochronology. Terra Nova, 8, 585592.

Reilinger, R.E., McClusky, S.C., OAl, M.B., King, R.W. \& Toksoz, M.N 1997. Global Positioning System measurements of present-day crustal movements in the Arabia-Africa-Eurasia plate collision zone. Journal of Geophysical Research, 102, 9983-9999.

Robertson, A.H.F. 1998. Mesozoic-Tertiary tectonic evolution of the Easternmost Mediterranean area: integration of marine and land evidence. In: Robertson, A.H.F., Emeis, K.C., Richter, C. \& Camerlenghi, A. (eds) Proceedings of the Ocean Drilling Program, scientific results, 160, 723-782.

Robertson, A.H.F. \& Dixon, J.E. 1984. Introduction: aspects of the geological evolution of the Eastern Mediterranean. In: Dixon, J.E. \& RobERTSON, A.H.F. (eds) The Geological Evolution of the Eastern Mediterranean. Geological Society, London. Special Publications, 17, 1-74.

SClater, J.G. \& Christie, P.A.F. 1980. Continental stretching: an explanation of the post Mid Cretaceous subsidence of the central North Sea basin. Journal of Geophysical Research, 85, 3711-3739.

ȘEngöR, A.M.C. \& Yilmaz, Y. 1981. Tethyan evolution of Turkey; A plate tectonic approach. Tectonophysics, 75, 181-241.

Șengör, A.M.C., Görür, N. \& ȘARoglu, F. 1985. Strike-slip faulting and related basin formation in zones of tectonic escape: Turkey as a case study. In: Biddle, K.T. \& Christie-Blick, N. (eds) Strike-slip deformation, basin formation and sedimentation. Society of Economic Plaeontologists and Mineralogists (SEPM) Special Publication, 37, 227-264.

Steckler, M.S. \& Watts, A.B. 1978. Subsidence of the Atlantic-type continental margin off New York. Earth and Planetary Science Letters, 41, 1-13.

Tatar, O., Piper, J.D.A., Gursoy, H. \& Temiz, H. 1996. Regional significance of neotectonic counterclockwise rotation in central Turkey. International Geology Review, 38, 692-700.
Tatar, O., Piper, J.D.A. \& Gursoy, H. 2000. Palaeomagnetic study of the Erçiyes Sector of the Ecemiş Fault Zone: neotectonic deformation in the southeastern part of the Anatolian Block. In: Bozkurt, E., WinCHESTER, J.A. \& PiPer, J.D.A. (eds) Tectonics and Magmatism in Turkey and the Surrounding Area. Geological Society, London. Special Publications, 175, 423-440.

Tekeli, O., Aksay, A., Urgun, B.M. \& Isik, A. 1984. Geology of the Aladağ Mountains. In: Tekeli, O. \& GöncüoĞLU, M.C. (eds) Geology of the Bolkar Mountains. Proceedings of the International Symposium on the Geology of the Taurus Belt, Ankara, 143-158.

TopraK, V. \& GöNCüOĞLU, M.C. 1993. Tectonic control on the development of the Neogene-Quaternary Central Anatolian Volcanic Province, Turkey. Geological Journal, 28, 357-369.

Turner, J. 1996. The subsidence of sedimentary basins. PhD thesis. Edinburgh University.

ÜnLÜGEnÇ, U. 1993. Controls on Cenozoic Sedimentation in the Adana Basin, Southern Turkey. PhD thesis. Keele University.

Ünlügenç, U., Demirkol, C. \& SafaK, U. 1993. Stratigraphical and sedimentological characteristics of the Karsanti Basin fill to the N-NE of the Adana Basin. In: Suat, A. (ed.) Erk Jeoloji Simpozyumu, Bildirileri, 215-227, [in Turkish with English abstract].

Westaway, R. 1994. Present day kinematics of the Middle East and eastern Mediterranean. Journal of Geophysical Research, 99, 12 071-12 090.

Westaway, R. 1999. Comment on "A new intracontinental transcurrent structure: the Central Anatolian Fault Zone, Turkey' by A. Koçyiğit and A. Beyhan. Tectonophysics, 314, 469-479.

Westaway, R. \& Arger, J. In press. Kinematics of the Malatya-Ovacik fault Zone. Geodynamica Acta, special issue on Neotectonics of Turkey.

Whitney, D.L. \& Dilek, Y. 1997. Core Complex development in central Anatolia, Turkey. Geology, 25, 1023-1026.

YalçIn, M.N. \& GörÜR, N. 1984. Sedimentological evolution of the Adana basin. In: Tekeli, O. \& GöncüOglu, M.C. (eds) Proceedings of the International Symposium on the Geology of the Taurus Belt, Ankara, $165-172$.

Yetiș, C. 1978. Geology of the amardi (Niğde) region and the characteristics of the Ecemiș Fault Zone between Maden Bogazi and Kamișli. Istanbul University Fen Fakultesi Mec. Series B, 43, 41-61.

Yetiș, C. 1984. New observations on the age of the Ecemiș Fault. In: TeKeli, O. \& GöncüOGlu, M.C. (eds) Proceedings of the International Symposium on the Geology of the Taurus Belt, Ankara, 159-164. 